\title{
HUMOROUS STORIES IN TEACHING READING COMPREHENSION OF EFL STUDENTS
}

\author{
Yusniati N. Sabata ${ }^{1}$, Lili Ihliyani Kupepe ${ }^{2}$ \\ ${ }^{1}$ PBI FKIP UM Luwuk, ${ }^{2}$ PBI FKIP UM Luwuk \\ Email: yusniati.n.sabata@gmail.com ${ }^{1}$, lili_ihliyani@yahoo.com²
}

\begin{abstract}
Abstrak
Tujuan penelitian ini adalah untuk mengetahui peningkatan kemampuan pemahaman membaca pada siswa kelas XI di SMA Muhammadiyah Luwuk. Untuk mengetahui apakah metode ini efektif atau tidak, peneliti menggunakan satu kelompok pre-test dan post-test untuk diterapkan di kelas sebelas. Penelitian ini melakukan delapan pertemuan. Pertemuan pertama adalah untuk pre-test dan enam pertemuan adalah untuk perlakuan, dan pertemuan terakhir adalah untuk post-test. Sebagai metode kuantitatif, peneliti menganalisis data menggunakan uji-t. Hasil penelitian menunjukkan bahwa ada perbedaan yang signifikan pada prestasi membaca siswa dengan cerita-cerita lucu. Dalam pre-eksperimen, rerata pre-tes siswa adalah 36,64 skor, dan rerata post-tes siswa adalah 82,14 skor. Hasil penelitian menunjukkan bahwa t-hitung $=8,73$ lebih besar dari t-tabel 1,771. Dengan kata lain, cerita lucu dapat meningkatkan pemahaman membaca siswa unuk kelas sebelas sekolah menegah atas.

Kata kunci: Cerita Humor; Pemahaman Membaca, EFL Students
\end{abstract}

\section{Abstract}

The purpose of this research is to find out the improvement of students' reading comprehension in eleventh grade at SMA Muhammadiyah Luwuk. To know whether the method is effective or not, the researcher used one-group pre-test and post-test to be applied in eleventh grade. The research conducted eight meetings. The first meeting was for pre-test and sixth meetings were for treatments, and the last meeting was for post-test. As the quantitative method, the researcher analyzed the data using t-test. The results showed that there was significant diffrence on the students' reading acievement with humorous stories. In the pre-experimental, the students' mean of pre-test was 36.64 scores, and the students' mean of post-test was 82.14 scores. The result showed that the t-counted $=8.73$ was greater than t-table 1.771. In other words, humorous stories can improve students' reading comprehension for the eleventh class of senior high school.

Keywords: Humorous Stories; Reading Comprehension; Mahasiswa EFL. 


\section{Introduction}

Reading is an important skill in language learning. It is the window of the world. By reading, people can get more knowledge and information from books, magazines, newspapers, and others. In language learning, reading is one of four skills that must be had by students. Mikulecky (2011) defines reading is a complex conscious and unconscious mental process in which the reader uses a variety of strategies to reconstruct the meaning that the author is assumed to have intended, based on the data from the text and the reader's prior knowledge. Further, Richard (2010) states that reading is the process by which the meaning of a written text is understood.

Reading is a process or brain activity to seek knowledge from many sources of written form. In the learning process, students must have the four skills, namely listening, reading, speaking, and writing. But many students that learn English as a foreign language always have problems in understanding the materials of the subject specifically in reading text. Therefore, this research only focusses on reading skills. Reading is given more emphasis among other language skills. Richard and Renandya (2002) explain that reading has a special spotlight in many second and or foreign language learning situations.

In the reading activity, students should have the ability to comprehend information from English written text well. Reading comprehension is a complex skill that requires an active interaction between text elements and the reader. The reader is an active participant with a text and the reader makes sense of how ideas on the text relate to one another by interpretive interactions between what the reader gleans from the text and what the reader already knows. From the statement, it is clearly understood that comprehension is the most important in reading. Since comprehension of the text is the ultimate goal in reading. Understanding comprehension processes is crucial to the study of reading.

Sudarwati (2007) states that reading comprehension is an analytical exposition text that elaborates the researcher's idea about the phenomenon surrounding to persuade the readers. Gehrer and Artelt (2013) define reading comprehension is related to literacy concept, which highlights functional facets of reading in occupational, educational, and informal settings. As stated by Finocchiaro (1974) to help students comprehend the written materials in the text, we should give the knowledge and ability to read other material with essays and enjoyable text. What is meant by other material here is the material outside the textbook. If the teacher can use some varieties in each lesson, the class will be motivated to learn. The ideas above encourage the writer to introduce humorous stories as one of the varieties of reading material.

Humor in teaching English can be applied to recharge students' brains. Using humorous stories in reading comprehension class is beneficial effects to stimulate students for having fun and enjoy during the learning process, as a result, they have strong motivation to comprehend the content of the reading passage. Martin and Kuiper (2016) illustrate that use humor in teaching as a beneficial manner to cope with stress and enhance their social and interpersonal relationship.

In reality, humorous stories are interesting and enjoyable in reading class. It stimulates the students to read more and train their comprehension of reading. As a result, it will be easier for the students to comprehend any other reading materials.

Deals with the explanation above, the main purpose of this research is to improve students' reading comprehension using humorous stories. As a result, the researchers conducted research using humorous stories at SMA Muhammadiyah Luwuk. This type of stories to make the students are interested in reading activity and improving students' reading comprehension. 
To support this research, there were two previous research relevant attached here. Firstly, research conducted by Junisy (2017) entitled: "The Use of Humor Text to Motivate the Students in Developing Reading Interest at Darul Salam Ihsan Boarding". The result showed that using humor text could make the class atmosphere more enjoyable and fun than that of other texts because the content of humor text is entertaining.

Secondly, research conducted by Hayati, Shooshtari and Shakeri (2011) entitled "Using Humorous Texts in Improving Comprehension of EFL Learners". The findings to the t-test which compared the scores of recall tests of both groups over the seven sections revealed no significant difference between the recall performances of two groups. The researchers suggested that a relatively influential role of humor and jokes on recall ability and reading comprehension and the implications might be for teachers to include humor and jokes in the reading texts that they provide for students.

\section{a. The Concept of Reading}

Tarigan (2008), reading is a process that is carried out and used by the reader to obtain a message which the writer. In reading activity sometimes becomes a huge problem for the students, even though they have to do it because it is their need in the process of learning especially language in the classroom. The students are impaired in reading because of some reason. Some of them are laziness, lack of interesting techniques, background knowledge, habit, and so on.

\section{b. Reading Comprehension}

Snow (2002) states that reading comprehension is the process of simultaneously extracting and constructing meaning through interaction and involvement with written language. Further, Klinger (2007) says that reading comprehension is the process of constructing meaning by coordinating the number of complex processes in reading activities including word reading, word and world knowledge, and fluency. All of them refer to the ability to interpret words, understand the meaning and the relationship between ideas conveyed in the text. Klinger summarized reading comprehension into three-step procedures, namely mentioning, practicing, and assessing.

In this research, the teaching of reading comprehension involves a two-stage process that is pre-teaching or preparation stage and comprehension stage which include skimming and scanning. In the pre-teaching stage, an advance organizer is used to give the students prior knowledge before reading text. The comprehension stage involves the skimming and scanning process in which the students search quickly for a general idea and specific information to comprehend the text.

\section{c. Types of Reading Comprehension}

There are two types of reading comprehension mentioned by Brown (2001). The first type consists of silent and oral reading. Silent type applies when the reader reads silently. While, oral reading applied when the reader read aloud the text with orally. The second type includes intensive and extensive reading. Intensive reading applied when the reader focuses on the linguistic details of the text. Meanwhile, extensive reading applied when the reader reads the text for pleasure.

d. Levels of Reading Comprehension

a) Literal Reading

Kennedy (1981) explains that literal reading is related to what a writer says, Literal reading results in this kind of reading comprehension. It requires the ability to: locate specific facts, identify happenings that are described directly, find answers to question based on given facts, classify or categorize information given and summarize the details expressed in a selection.

b) Interpretative Reading 
Kennedy (1981) looks at inferential comprehension as about what the writer means. He adds that there are a least four skills that are essential for effective use inferential reading: Finding implied meanings, anticipating outcomes, making generalizations and drawing conclusions.

c) Critical Reading

Critical reading is the way of getting information and ideas within a text (Kurland 2000). Critical reading is good to be implemented because it does not only develop the cognitive aspect (understanding the text) but also the affective aspect (reading behavior). Therefore, a teacher does not only ask students to read and understand a text, but he should also expose strategies on how to read effectively.

d) Creative Reading

Burns (1984) says that is concerned with the production of new ideas, the development of new insights, fresh approaches, and original constructs. Creative readers must be skilled in the areas discussed as follows: a) Cause and effect; b) Visualization; c) Making value judgments; d) Solving problem; e) Predicting outcomes; and f) Improving story presentation.

e. Humorous Stories

Humorous stories constitute the most effective motivational device since they provide laughter, fun, entertainment, and emotional participation. However, they are sometimes difficult to be understood.

Flemming (1981) says that a humorous passage is sometimes difficult to read. This famous line by Bertrand Russell points out the difference in the emotional meanings of words very well. Besides, readers must draw upon their knowledge of recent events to appreciate the joke such as political humor. They may understand every line of humorous passage but they may not see what is funny about it. This often happens because humor is culturally based on what one country finds funny, another country may not find so at all. Thus, humor must be universal. Humor is only successful it the situation depicted is not too culture-specific.

f. Types of Humorous Stories

Types of humor from Bryant, Comisky, Crane \& Zillmann (1980): a) Riddles is a message presented in the form of an information question with an answer provided in a humorous punch line. Riddles are cultural and linguistic puzzles the answer to a riddle is funny because it is unexpected, it requires seeing something different and it may involve using words differently. b) Pun is an instance in which structurally or phonetically similar words or phrases having two or more meanings are used in such a way as to simultaneously play on their multiple meanings. According to Lems (2013), puns are a special form of humor based on double meanings. Puns contain a double meaning. Double meaning of two words that sound very similar, sound the same and look the same. c) Funny story is an instance in which the teacher relates a series of connected events or the activities of a single incident as a tale.

\section{Research Method}

This research conducted in SMA Muhammadiyah Luwuk, consisted of 14 students of the eleventh grade, it refers to Sugiono's excerption (2011). It used a pre-experimental research design, namely the one-group pre-test and post-test. The instrument of data collection used reading comprehension tests with pre-test and post-test. The pre-test was given to students before the treatment and the post-test was given after the treatment. While the technique of collecting data used pre-test, treatment, then post-test. 
The variable of this research consisted of two variables, namely the dependent variable and the independent variable. The dependent variable was reading comprehension that is the reading with full understanding to obtain maximum information of the text. And then the independent variable was humorous stories.

This research attached excerption from Frankle and Wallen (2006), Gal, Gall, and Borg (2007), the experimental research methods including various experimental designs provide the most sound and strongest way to establish a cause-effect relationship and to control external variables effectively. Pre-experimental research can be done to investigate the learning problem by applying treatment toward the subject of research.

This research classified as a pre-experimental design because it was control of extraneous variables. In the one-group pretest-posttest design, a single group was measured or observed not only after being exposed to a treatment of some sort, but also before. To analyze experimental data using pre-test and post-test one-group design data, then using the t-test formula (Arikunto, 2006):

\section{$\begin{array}{lll}\text { T1 } & \mathrm{X} & \mathrm{T} 2\end{array}$}

Where:
T1: Pre-test
$\mathrm{X}$ : Treatment
T2: post-test

To analyze the data of this research, the researchers used statistical analysis formula proposed by Arikunto (2006) as follows:

Where:

$$
\sum=\frac{x}{n} x 100
$$

$$
\begin{aligned}
\sum & =\text { individual score } \\
\mathrm{x} & =\text { obtained score } \\
\mathrm{n} & =\text { maximum score }
\end{aligned}
$$

Mean score formula as follows:

Where:

$$
\mathrm{M}=\frac{\sum X}{N}
$$

$\mathrm{M} \quad=$ the mean of the score

$\sum X \quad=$ the sum of the score obtained by students

$\mathrm{N} \quad=$ Number of students

Mean deviation as follows:

Where:

$$
M d=\frac{\sum d}{N}
$$

Md = mean score of deviation

$\sum d=$ the sum of deviation

$N \quad=$ the number of students

After that, the researchers computed the square deviation by employing formula purposed by Arikuto (2006) as follows:

Where:

$$
\sum_{X^{2}} d=\sum_{d^{2}}-\left(\frac{\left(\sum d^{2}\right)}{N}\right)
$$

$$
\begin{array}{ll}
\sum_{X^{2}} d & =\text { the square deviation } \\
\sum_{d^{2}} & =\text { sum of square deviation } \\
\mathrm{N} & =\text { number of students }
\end{array}
$$


After computing all formula above, the researchers showed the significance between the mean pre-test and post-test by using the formula as follows:

Information:

$$
\mathrm{t}=\frac{M d}{\sqrt{\left[\frac{\sum X d^{2}}{\mathrm{~N}(\mathrm{~N}-1)}\right]}}
$$

Md : Mean from division (d) between

post-test and pre-test

Xd : Difference in deviation with

mean deviation

$\sum \mathrm{Xd}^{2}:$ Number of squares of deviation

$\mathrm{N}$ : Number of subject

Df : or $\mathrm{db}$ is N-1

This formula was used to calculate the effectiveness of the treatment given to the research subjects. This formula was used for the research design of a single subject. The results of this data then were analyzed by using the t-count formula then the results obtained could indicate whether the treatment given was effective or not.

Testing Hypothesis

After conducting statistical calculations to find the value of t-count by comparing the deviation of the results of the pre-test and post-test, the researchers tested the hypothesis which aims to prove the effectiveness of treatment whether treatment essay tests and some could be taught at the second-grade students of SMA Muhammadiyah Luwuk through humorous stories or not. If $\mathrm{t}$-counted is higher than the $\mathrm{t}$-table. It means that the hypothesis is accepted of there is a significant influence. However, if the t-count is lower than the t-table, the hypothesis is rejected. In other words, improving reading students' through humorous stories is failed.

\section{Findings and Discussion}

The researchers present the result and analysis of the data obtained through the test (pre-test and post-test) during the process of conducting the research. The data were collected by using one kind of instrument and it was analyzed statistically.

a. Result of Pre-test

The researchers applied two kinds of tests, they were pre-test and post-test. The number of the students was 14 and all of them attended the pre-test and post-test. The maximum score of the test was 75 used essay tests consisting of 5 items.

The pre-test was administered to the class aimed to measure the students' abilities before being treated. The result of pre-test as follows:

\begin{tabular}{ccc}
\multicolumn{3}{c}{ Table 1. The Pre-test score of Students } \\
\hline Number & Initial & Obtain Score \\
\hline 1 & ASA & 35 \\
2 & MSH & 45 \\
3 & NWS & 25 \\
4 & NMT & 45 \\
5 & RAM & 35 \\
6 & ASL & 35 \\
7 & HAP & 45
\end{tabular}


BEEJ, e-ISSN 0000-0000, Vol. 1, No. 1, March 2020

\begin{tabular}{ccc}
8 & DSL & 30 \\
9 & RKZ & 45 \\
10 & ASD & 30 \\
11 & FRK & 30 \\
12 & HRT & 25 \\
13 & RTM & 35 \\
14 & ERD & 25 \\
\hline Total Score & & 485
\end{tabular}

Further, the computation of mean score as follows:

$$
\begin{array}{rlr}
M & =\frac{\sum X}{N} & =\frac{485}{14} \\
& =34.64
\end{array}
$$

There score above (34.64) was the pre-test mean score of the class.

b. The Highlight of Treatment

In the first meeting, the researchers conducted a pre-test for the students in the preexperimental design. Then, the researchers gave treatment to the pre-experimental design in six meetings. There were sixth meeting for applied the treatment because two meetings included pre-test and post-test. The researchers applied the treatment in the second meeting. Every meeting, the students must fill 5 questions on the paper with the time of about 75 minutes.

The reading text given to the students can be seen below:

1. Pre-test

: "Funny Tale of a Lost Senior Citizen".First treatment: "Fisherman and Environmentalist".

2. Second Treatment : "Gonna Fishing".

3. Third Treatment : "Camel and His Baby".

4. Fourth Treatment : "Carriage Box in the School".

5. Fifth Treatment : "The Hanging Ceiling Fan".

6. Sixth Treatment : "Intelligent Man Buying a Land".

7. Post-test : "The Lazy Dreamer".

c. Result of Post-test

The result of the students' score in post-test is presented in table 2.

Table 2. The Post-test Score of Students

\begin{tabular}{ccc}
\hline Number & Initial & Obtain Score \\
\hline 1 & ASA & 80 \\
2 & MSH & 85 \\
3 & NWS & 80 \\
4 & NMT & 90 \\
5 & RAM & 80 \\
6 & ASL & 85 \\
7 & HAP & 85 \\
8 & DSL & 90
\end{tabular}


BEEJ, e-ISSN 0000-0000, Vol. 1, No. 1, March 2020

\begin{tabular}{ccc}
9 & RKZ & 85 \\
10 & ASD & 80 \\
11 & FRK & 75 \\
12 & HRT & 80 \\
13 & RTM & 80 \\
14 & ERD & 75 \\
\hline Total Score & & 1150 \\
\hline
\end{tabular}

After calculating the students' score on the post-test the researchers computed the mean score of the students' post-test. The computation was same as the pre-test one. The comutation as follow:

$$
\begin{aligned}
M & =\frac{\sum X}{N} \\
& =\frac{1150}{14} \\
& =82.14
\end{aligned}
$$

The score above (82.14) was the post test mean score of the class.

d. Result of the Students' Square Deviation

\begin{tabular}{|c|c|c|c|c|c|}
\hline \multirow{2}{*}{$\begin{array}{l}\dot{\bar{\Xi}} \\
\text { छ } \\
\text { Z }\end{array}$} & \multirow{2}{*}{ Initial } & \multicolumn{2}{|c|}{$\begin{array}{l}\text { Students' } \\
\text { Score }\end{array}$} & \multirow{2}{*}{ 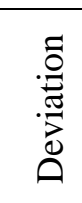 } & \multirow{2}{*}{$\mathrm{D}^{2}$} \\
\hline & & $\begin{array}{l}\text { Pre- } \\
\text { Test }\end{array}$ & $\begin{array}{c}\text { Post- } \\
\text { Test }\end{array}$ & & \\
\hline 1 & ASA & 35 & 80 & 45 & 2025 \\
\hline 2 & MSH & 45 & 85 & 40 & 1600 \\
\hline 3 & NWS & 25 & 80 & 55 & 3025 \\
\hline 4 & NMT & 45 & 90 & 45 & 2025 \\
\hline 5 & RAM & 35 & 80 & 45 & 2025 \\
\hline 6 & ASL & 35 & 85 & 50 & 2500 \\
\hline 7 & HAP & 45 & 85 & 40 & 1600 \\
\hline 8 & DSL & 30 & 90 & 60 & 3600 \\
\hline 9 & RKZ & 45 & 85 & 40 & 1600 \\
\hline 10 & ASD & 30 & 80 & 50 & 2500 \\
\hline 11 & FRK & 30 & 75 & 45 & 2025 \\
\hline 12 & HRT & 25 & 80 & 55 & 3025 \\
\hline 13 & RTM & 35 & 80 & 45 & 2025 \\
\hline 14 & ERD & 25 & 75 & 50 & 2500 \\
\hline \multicolumn{2}{|c|}{ Total Score } & 485 & 1150 & 665 & 32075 \\
\hline
\end{tabular}

The rusult of the student's square deviation can be seen on table 3 .

Table 3. The Standard Deviation of the Sample

After getting the mean score, the researchers continued to calculate the standard deviation of the sample. The data can be seen in the following formula: 


$$
\begin{aligned}
M d & =\frac{\sum d}{N} \\
M d & =\frac{665}{14} \\
M d & =47.5
\end{aligned}
$$

The researchers then computed the square deviation as shown below:

$$
\begin{aligned}
\sum_{X^{2}} d & =\sum_{d^{2}}-\left(\frac{\left(\sum d^{2}\right)}{N}\right) \\
& =37025-\frac{665^{2}}{14} \\
& =37025-31.587 \\
& =5.438
\end{aligned}
$$

To know the significant difference between pre-test and post-test, the researchers used the statistical analysis as follows:

$$
\begin{aligned}
& t=\frac{M d}{\sqrt{\left[\frac{\sum d^{2}}{\mathrm{~N}(\mathrm{~N}-1)}\right]}} \\
& t=\frac{4.5}{\sqrt{\left[\frac{5.438}{14(14-1)}\right]}} \\
& t=\frac{47.5}{\sqrt{\left[\frac{5.438}{182}\right]}} \\
& t=\frac{47.5}{\sqrt{[29.87]}} \\
& t=\frac{47.5}{5.44} \\
& t=8.73
\end{aligned}
$$

From the above computation, the researchers found that the significant difference between the result of the pre-test and post-test is 8,73. To find the interpretation, the researchers compared the t-counted and t-table by looking at to the following indicators.

Level of Significance $=0,05$

$\begin{array}{ll}\text { Degree of Freedom } & =\mathrm{N}-1 \\ & =14-1 \\ & =13 \\ \text { t-table }(0,05.13) & =1.771 \\ \mathrm{t} \text {-count } & =8.73\end{array}$

Based on the above calculation, it can be seen that the t-counted is greater than ttable (t-counted > t-table).

e. Testing Hypothesis

The researchers made the hypothesis to prove the effectiveness of improving students' reading comprehension using humorous stories or not. The criteria for hypothesis testing are as follows:

1. If the t-counted is higher than the t-table, the alternative hypothesis is $(\mathrm{Ha})$ is accepted.

2. If the t-counted is the same or even lower than the t-table, the alternative hypothesis (Ha) is rejected.

Based on the criteria and after analyzing the data of the test by using the t-test formula, the researchers found that t-counted was 8.73. Then, to find out the significant difference between the pre-test and post-test mean score, the researchers compared the value of t-counted with the value of t-table. The degree of freedom $(d f)$ of the t-table is $14-1=13$, in applying 0.05 level significance. The value of t-table is 1.771 . 
It shows that the value of $\mathrm{t}$-counted is higher than the value of the $\mathrm{t}$-table. It means that there was a significant difference in students' ability of the eleventh year of SMA Muhammadiyah Luwuk after learning reading comprehension using humorous stories. In conclusion the use of humorous stories can improve reading comprehension of the eleventh-grade students.

The research was conducted to find out the improvement of students' reading comprehension after using humorous stories. Humorous stories are one of many learning media that could be used by the teacher in teaching English especially in reading comprehension.

This research had proved that humorous stories were effective to be used in teaching reading in narrative text. It can be seen in the table of students' score improvement from the pre-test until the post-test. The improvement was because the application of humorous stories made more help stimulate students' thinking in learning reading in narrative text.

Based on the result of the quantitative data, the result showed that the students improved their reading comprehension in narrative text. The students' score was getting better from the first meeting until the last meeting. The mean of the students' scores in the pre-test was 34.64. It was low because the score was average below completeness. The mean of students' scores in the post-test was 82.14. It was higher than the pre-test.

Based on the result of the quantitative data taken from the reading comprehension test, it was found that the class ran effectively. The students paid attention to the teacher during the teaching-learning process. They showed spirit in reading and enjoying the learning process. Then, it can be said that the quantitative data also showed the improvement of the teacher's and the students' activities during the teaching-learning process. From the explanation above, it could be concluded that the results of the research show the humorous stories could improve the students' reading comprehension in narrative text.

\section{Conclusion}

After analyzing the data, the researchers concluded that humorous stories can be used in teaching reading in the class to improve students' reading comprehension. It can be seen from the statistical analysis that t-counted is 8.73 by applying 0.05 level significance with 14 (14-1) degrees of freedom $(d f)$. The researchers found that t-counted (8.73) is greater than the t-table (1.771). Thus, the data showed that the hypothesis of this research is accepted. It means humorous stories are effective to improve the students' reading comprehension.

\section{References}

Arikunto, Suharsimi. (2006). Research Procedures a Practical Approach. Jakarta: Rineka Cipta.

Burns, P.C, Roe, B., \& Ross, E.P. (1984). Teaching Reading in Today's Elementary School (Third Edition). Boston: Houghton Mifflin Company.

Brown, H. G. (2001). Teaching by Principles: Interactive Approach to Language Pedagogy. New York. Longman.

Bryant, J., Crane, J. S., Comisky, P. W. \& Zillmann D. (1980). Relationship Between College Teachers' Use of Humor in the Classroom and Students' Evaluations of Their Teachers. Journal of Educational Psychology, 72: 4, 511 -519. (accessed 26/07/2019).

Finocchiaro, Mary. (1974). English as a Second Language : From Theory to Practice. New York: Regents Publishing Company. 
Flemming, Paulla. Fat, and Lee Kaii (1981). Better Reading Skills. Hongkong: Oxford University Press.

Gehrer, K. And Artelt, C. (2013). bildungslaufbahn: Das Bildungspanel NEPS. [Literacy and educa-tion career: The National Education Panel Study NEPS]. In A. BertschiKaufmann \& C. Rosebrock (Eds.),Literalität erfassen: bildungspolitisch, kulturell, individuell, (pp. 168-188). Weinheim und Basel: BeltzJuventa.

Hayati, Shooshtari and Shakeri. (2011). Using Humorous Texts in Improving Comprehension of EFL Learners. Theory and Practice in Language Studies. Vo. 1. No. 6. pp. 652-661. ISSN 1799-2591. June 2011: Academy Publisher Manufactures in Finland.

Junisy, Muahmmad. (2017). The Use of Humor Text to Motivate The Students in Developing Reading Interest at Darul Salam Ihsan Boarding. Thesis. UIN ArRaniry Banda Aceh. $p d f$

Kennedy, Eddie C. (1981). Methods in teaching Development Reading $2^{\text {nd }}$ edition. United Stated of America: Peacock Publisher, Inc.

Kurland, Daniel J. (2000). Critical Reading vs.Critical Thinking. Retrieved from www.criticalreading.com on september 2019.

Lems. Kristin. (2013). Laughing All the Way: Teaching English Using Puns. English Teaching Forum. Number 1. Re Retrieved from https://files.eric.ed on 30 September 2019.

Martin, Rod,. and Nicholas A. Kuiper. (2016). Three Decade Investigating Humor and Laughter: An Interview with Professor Rod Martin. Europe's Journal of Psychology. 12(3), 498. 2016. pdf

Mikulecky, B. S. (2011). A Short Course in Teaching Reading: Practical Technique for Building Reading Power. United States: Pearson Longman.

Richard, and Renandya. (2002). Methodology in Language Teaching: An Anthology of Current Practice. Cambridge University.

Richard, and Richard, Smith. (2010). Longman Dictionary of Language Teaching and Applied Linguistics. Fourth Edition.. Great Britain: Pearson Eduction Limited.

Snow, C.E (2002). Reading for Understanding: Toward an Reading and Development Program in Reading Comprehension. U.S: RAND

Sudarwati. (2007). Look Ahead Book 2. Jakarta: Erlangga.

Sugiono. (2011). Quantitative Research Method, Qualitative and $R$ \& D. Bandung: Alfabeta

Tarigan, H.G (2008). Reading As a Language Skill. Bandung: Space 